\title{
Body composition and habitual and match-day dietary intake of the FNB Maties Varsity Cup rugby players
}

\author{
S Potgieter, BSc Dietetics, M Nutr, PhD Nutr Sci; J Visser, BSc Dietetics, M Nutr; I Croukamp, BSc Dietetics; M Markides, BSc Dietetics; \\ J Nascimento, BSc Dietetics; K Scott, BSc Dietetics
}

Division of Human Nutrition, Department of Interdisciplinary Health Sciences, Faculty of Medicine and Health Sciences, Stellenbosch University, Tygerberg, Cape Town, South Africa

Corresponding author: S Potgieter (sunita@sun.ac.za)

\begin{abstract}
Background. Rugby is a physically demanding body contact sport. Optimising dietary intake and body composition can positively affect the performance of rugby players.

Objectives. To determine the body composition, habitual and game-specific nutritional practices of FNB Maties Varsity Cup (MVC) rugby players.

Methods. A descriptive, cross-sectional study with an analytical component was conducted. Of all the MVC rugby players (N=35), 18 completed the sections on body composition and match-day dietary intake, while 11 completed the habitual dietary intake section. Body composition data were collected by an International Society for the Advancement of Kinanthropometry-accredited biokineticist. Habitual dietary intake data (via a self-administered 7-day food record) and match-day dietary strategies (via telephonic 24-hour recall interview) were collected and compared with nutritional requirements reported by the International Olympic Committee, the American Dietetic Association, the American College of Sports Medicine and the International Society of Sport Nutrition.

Results. Forwards had significantly higher weight $(p=0.01)$, sum of seven skinfolds $(p=0.01)$, percentage body fat $(p=0.02)$, fat mass $(p=0.01)$ and fat-free mass $(p=0.01)$ than backs. Compared with current recommendations, group habitual dietary intake (mean (standard deviation)) was inadequate for total energy (45.4 (9.0) kcal/kg body weight (BW)), carbohydrate (4.3 (0.4) g/kg BW), polyunsaturated fatty acids (6.2 (1.7)\% of total energy (TE)), calcium:protein ratio (6.5:1 (3.5:1)) and copper (2.3 (0.4) mg), while displaying higherthan-recommended intakes for total protein $(2.4(0.7) \mathrm{g} / \mathrm{kg} \mathrm{BW})$, fibre (37.7 (7.3) g/day), total fat (33.8 (4.3)\% TE), saturated fatty acids $(11.2(13.1) \%$ TE), cholesterol $(766.3(371.8) \mathrm{mg})$ and niacin $(45.2(6.9) \mu \mathrm{g})$. Habitual supplement use was high at $91 \%(n=10 / 11)$. Nutritional match-day strategies were excessive for protein $(1.2(0.6) \mathrm{g} / \mathrm{kg} \mathrm{BW})$ and fat $(0.9(0.4) \mathrm{g} / \mathrm{kg} \mathrm{BW})$ in the pre-event meal, inadequate for energy and carbohydrate during the game and excessive for alcohol (54.4 (59.9) g) after the game.

Conclusion. Forwards and backs differed significantly in various body composition measurements. In relation to observed practices, habitual dietary intake and nutritional match-day strategies were suboptimal, with high reported supplement use. Players in this sport potentially could benefit from specialist input to optimise dietary strategies and body composition in order to enhance performance.
\end{abstract}

S Afr J SM 2014;26(2):35-43. DOI:10.7196/SAJSM.504

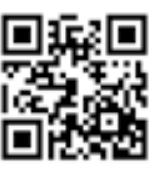

After soccer, rugby is the most popular South African (SA) sport, with a following of $\sim 10$ million. ${ }^{[1]}$ Development and implementation of new programmes at school, club and university level is one of the SA Rugby Union (SARU)'s aims to reap the long-term benefits in the sport. The annual SARU 2012 report emphasised that the successful implementation of the FNB Varsity Cup presented by Steinhoff International reinvigorated university-level rugby and provided the ideal stage on which players can display their skills. ${ }^{[2]}$ This interuniversity competition (comprising eight teams) was initiated in 2008 and is the third leading domestic rugby competition in SA. ${ }^{[2]}$ The Maties, a participating team from Stellenbosch University, has won the competition three times since its inception. The Stellenbosch Rugby Football Club is probably one of the biggest competitive rugby clubs in the world, producing 171 Springboks to date, and constituting the nucleus of the rugby teams of the Western Province. ${ }^{[3]}$
Rugby is a physically demanding body contact sport. Rugby players should be physically fit, skilled, fast, alert and psychologically stable. ${ }^{[4]}$ The aforementioned factors increase rugby performance by reducing mistakes on the field and the risk of injury. ${ }^{[4]}$ Underpinning increased performance are good discipline and optimal nutrition. ${ }^{[4]}$ Often within a sport there is variability in the physical characteristics of players. In rugby, there are two broad positions of play, namely forward players (forwards) and backline players (backs). These positions demand different exercise patterns, physical characteristics and nutritional needs. ${ }^{[5]}$ The physical characteristics of elite, ${ }^{[5,6]}$ amateur, ${ }^{[7]}$ adolescent ${ }^{[8-10]}$ and pre-adolescent rugby players have been documented, and it appears that there are well-defined differences between the physical and morphological characteristics of forwards and backs, especially in terms of height and body weight (BW). ${ }^{[5]}$

When talented, motivated and highly trained athletes meet to compete, the border between victory and defeat is usually minute; 
therefore, when everything else is equal, optimal nutrition can be the difference between winning and losing. Thus, an adequate diet and nutrient intake can positively affect the performance of athletes. ${ }^{[1]}$ In terms of sport nutrition guidelines, rugby is classified as a field game, utilising strength and power, with patterns of intermittent activity between bursts of high intensity play, followed by rest pauses or periods of lower activity. ${ }^{[12]}$ The work-to-rest ratio can be used to describe a stop-start game such as rugby. The work-to-rest ratio is typically higher for forwards (1:6 - 7) compared with backs (1:20). ${ }^{[13]}$

The nutritional requirements of rugby players differ depending on playing position, duration and frequency of matches, length of the rugby season, training phase and, as discussed above, positionspecific tasks and physique requirements. ${ }^{[12]}$

\section{Objective}

To the researchers' knowledge, a comprehensive study of the combination of body composition, and habitual and match-day dietary intake of semi-professional and professional rugby players in SA has not been published. The objective of the study was therefore to establish the body composition, habitual and game-specific nutritional practices of Maties Varsity Cup (MVC) rugby players. This information can form the basis of future strategies that can be implemented to optimise the dietary intake and body composition of these players.

\section{Methods}

\section{Selection and description of participants}

A descriptive, cross-sectional study with an analytical component was conducted. The study population consisted of male MVC rugby players. Census sampling was used to select the participants for the study. The study was approved (N09/10/272) by the Health Research Ethics Committee of the Faculty of Medicine and Health Sciences, Stellenbosch University. Subjects gave written informed consent to participate in the study and were assigned a specific reference number linked to their names. This was necessary owing to the fact that data collection took place over a 2-month period that fell within the competitive season (January - February 2009). The list of names, reference numbers and contact details was destroyed following data collection to ensure complete confidentiality and anonymity.

\section{Technical information}

The study consisted of three main components, assessing (i) body composition, (ii) habitual dietary intake and (iii) game-specific dietary intake. A level 1 International Society for the Advancement of Kinanthropometry-accredited biokineticist collected anthropometric data. Body mass index (BMI) was determined from the weight and height of the players. The sum of seven skinfolds (SKFs), fat mass, fat-free mass (FFM) and percentage body fat were also determined. The BMI was interpreted according to the World Health Organization (WHO) standard guidelines. ${ }^{[14]}$ The sum of seven SKFs from the bicep, tricep, subscapular, supraspinale, abdominal, front thigh and medial calf was obtained and interpreted according to normative data for international- and national-level male athletes. ${ }^{[15]}$ Percentage body fat was calculated using the age of the subject in a gender-specific equation incorporating SKF thickness at four anatomical sites. ${ }^{[16]}$ For all anthropometrical measurements, the average of two measurements was used and where consecutive measurements differed significantly, the median was used.

Habitual dietary intake data were collected via a self-administered 7-day food record, and match-day dietary strategies were collected via a telephonic 24-hour recall interview the day after a Varsity Cup match was played. Final-year BSc Dietetics students from Stellenbosch University collected data under supervision of two registered dietitians. Portion sizes in the food record were quantified using standard household measurements and units. The quantities of supplements, such as energy gels and bars, were recorded as the amounts indicated on the packaging. Portion sizes with the telephonic 24-hour recall were described using household measures. Dietary data were analysed with Food Finder TM3 for Windows software application, version $1 .^{[17]}$ Only the macronutrient content of supplements was quantified and added to the total habitual dietary intake. Habitual and training/game-specific dietary macronutrient intake was compared with international references. ${ }^{[11,12]}$ Estimated energy availability ( ${ }_{\text {est }}$ EA) was calculated according to the International Olympic Committee (IOC) guidelines. ${ }^{[11]}$ Micronutrient intake values were compared with the dietary reference intakes (DRIs) and a cut-off value of $<67 \%$ was deemed inadequate. ${ }^{[18]}$ The ratio of calcium:protein was determined and compared with recommendations (20 $\mathrm{mg}$ of calcium per $1 \mathrm{~g}$ protein). ${ }^{[19]}$

\section{Statistics}

Statistical analysis was completed with the assistance of a biostatistician from the Centre for Statistical Consultation, Stellenbosch University. Data capturing and statistical analysis programs used included Statistica (version 11) and Microsoft Excel (2010) for Windows 7. Descriptive statistics were reported as means (standard deviations (SDs)) for continuous data. To test the difference between the forwards and backs, analysis of variance (ANOVA) was performed. In the case of data not being normally distributed, the Kruskal-Wallis test was used to test the difference. Differences between the two groups were considered statistically significant where $p<0.05$.

\section{Results}

\section{Demographic information}

A total of 35 players took part in the study, of which 13 were forwards and 16 were backs ( 6 players did not indicate their position of play). The mean (SD) age of the group was 21.9 (1.2) years. The demographic and training characteristics of the players are summarised in Table 1.

\section{Body composition}

Body composition data, with specific reference to weight, sum of seven SKFs, percentage body fat, fat mass and FFM differed significantly between forwards and backs (Table 2).

\section{Habitual dietary intake}

Eleven players returned full data sets (7-day food record). Due to the limited number of returned food records from the backs $(n=1)$, data were not compared between forwards and backs. However, when comparing the group's habitual macronutrient dietary intake to the recommendations (Table 3), it was found that the group had an inadequate intake of total energy (TE), carbohydrate and 
Table 1. Demographic and training characteristics

\begin{tabular}{|c|c|c|c|c|}
\hline & $\begin{array}{l}\text { All players }{ }^{*}(N=35), \\
\text { mean }(S D)\end{array}$ & $\begin{array}{l}\text { Forwards }(n=13), \\
\text { mean }(\mathrm{SD})\end{array}$ & $\begin{array}{l}\text { Backs }(n=16), \\
\text { mean }(S D)\end{array}$ & $p$-value \\
\hline Age (years) & $21.9(1.2)$ & $22.1(1.2)$ & $22.0(1.2)$ & 0.50 \\
\hline Exercise/day (minutes) & $121.0(18.2)$ & $120.7(6.5)$ & $123.2(16.9)$ & 0.74 \\
\hline Rugby training/week (hours) & $7.5(1.1)$ & $7.6(1.3)$ & $7.4(1.2)$ & 0.77 \\
\hline Other training/week (hours) $^{\dagger}$ & $5.4(1.7)$ & $5.3(2.2)$ & $5.6(1.7)$ & 0.63 \\
\hline Matches played/week (minutes) & $98.3(34.1)$ & $98.5(35.1)$ & $105.0(38.3)$ & 0.63 \\
\hline
\end{tabular}

Table 2. Body composition

\begin{tabular}{|c|c|c|c|c|c|c|}
\hline & \multicolumn{2}{|c|}{ Reference range } & \multirow{3}{*}{$\begin{array}{l}\text { All players } \\
(n=18),{ }^{*} \\
\text { mean (SD) }\end{array}$} & \multirow{3}{*}{$\begin{array}{l}\text { Forwards } \\
(n=7), \\
\text { mean (SD) }\end{array}$} & \multirow{3}{*}{$\begin{array}{l}\text { Backs } \\
(n=11), \\
\text { mean (SD) }\end{array}$} & \multirow[t]{3}{*}{$p$-value } \\
\hline & & & & & & \\
\hline & International data & National data (Boksmart) ${ }^{[20]}$ & & & & \\
\hline \multicolumn{3}{|l|}{ Height (m) } & $1.8(0.1)$ & $1.9(0.1)$ & $1.8(0.1)$ & 0.16 \\
\hline Forwards, mean (SD) & $1.9(0.1)^{[21]}$ & $1.810(0.050)-1.977(0.040)$ & & & & \\
\hline Backs, mean (SD) & $1.8(0.08)^{[21]}$ & $1.793(0.065)-1.813(0.055)$ & & & & \\
\hline \multicolumn{3}{|l|}{ Weight (kg) } & $95.5(13.6)$ & $107.0(11.2)$ & $86.9(7.7)$ & $0.01^{\dagger}$ \\
\hline Forwards, mean (SD) & $111.1(2.9)^{[21]}$ & $102.4(905)-118.4(8.0)$ & & & & \\
\hline Backs, mean (SD) & $95.7(2.3)^{[21]}$ & $88.7(8.3)-100.2(14.1)$ & & & & \\
\hline BMI $\left(\mathrm{kg} / \mathrm{m}^{2}\right)$ & $18.5-24.9^{[14]}$ & - & $29.2(3.7)$ & $32.5(3.3)$ & $27.1(2.1)$ & $0.01^{\dagger}$ \\
\hline $\begin{array}{l}\text { Sum of seven skinfolds } \\
(\mathrm{mm})^{\ddagger}\end{array}$ & $36.8-85.9^{[15]}$ & - & $80.5(27.2)$ & $100.3(20.5)$ & $67.9(23.5)$ & $0.01^{\dagger}$ \\
\hline Forwards, mean (SD) & - & $73.3(19.5)-111.3(25.3)$ & & & & \\
\hline Backs, mean (SD) & - & $57.1(14.8)-62.0(17.0)$ & & & & \\
\hline Body fat (\%) & $8-17^{[5]}$ & - & $18.2(5.7)$ & $21.9(4.4)$ & $15.8(5.3)$ & $0.02^{\dagger}$ \\
\hline Forwards, mean (SD) & - & $15.2(2.9)-20.0(3.1)$ & & & & \\
\hline Backs, mean (SD) & - & $12.3(2.2)-13.7(2.8)$ & & & & \\
\hline Body fat (kg) & - & - & $18.4(7.8)$ & $24.8(6.4)$ & $14.3(5.6)$ & $0.01^{\dagger}$ \\
\hline FFM $(\mathrm{kg})$ & - & - & $79.7(9.0)$ & $87.8(7.7)$ & $74.6(5.1)$ & $0.01^{\dagger}$ \\
\hline \multicolumn{3}{|c|}{$\begin{array}{l}\text { * Complete sets of anthropometry could be obtained from the biokineticist for } n=18 \text { players. } \\
\text { 'Indicates statistically significant difference between forwards and backs. }\end{array}$} & & & & \\
\hline
\end{tabular}

polyunsaturated fatty acids (PUFAs), while displaying higherthan-recommended intakes for total protein, fibre, total fat and saturated fatty acids (SFAs). In addition to the high intake of total fats and SFAs, the mean (SD) cholesterol intake also exceeded recommendations $(766.3$ (371.8) $\mathrm{mg}$ v. the recommendation of 300 - $500 \mathrm{mg} /$ day). ${ }^{[18]}$

All the mean micronutrient intakes fell within the recommended DRI ranges, except for copper intake $(2.3(0.4) \mathrm{mg}, 26 \%$ of the DRI of $9.0 \mathrm{mg} /$ day), which was low, and niacin intake (45.2 (6.9) $\mathrm{mg}, 283 \%$ of the DRI and above the upper limit (UL) of $35 \mathrm{mg} /$ day), ${ }^{[18]}$ which was high. Although the calcium intake of the players was adequate (1 250 (403) mg/day v. the DRI of $1000 \mathrm{mg} /$ day and below the UL of $2500 \mathrm{mg} /$ day) ${ }^{[18]}$ when evaluating the calcium intake in relation to the protein intake (calcium:protein ratio), it was notably low (6.5:1 $(3.5: 1) \mathrm{v}$. the recommendation of $20: 1) .^{[19]}$

\section{Dietary supplement use}

Of the eleven 7-day food records received showing habitual dietary intake, 10 players indicated supplement use (91\%). Of these players, $50 \%(n=5)$ indicated they used supplements to provide more energy, $60 \%(n=6)$ to increase muscle mass/weight gain, $40 \%(n=4)$ to enhance performance, $70 \%(n=7)$ to recover from exercise, $30 \%(n=3)$ to prevent illness and $10 \%(n=1)$ for hydration, stress relief or no reason. Supplements used included exercise performance enhancers, weight 
Table 3. Habitual dietary macronutrient intakes

\begin{tabular}{|c|c|c|}
\hline & $\begin{array}{l}\text { Reference } \\
\text { range }^{* \dagger}\end{array}$ & $\begin{array}{l}\text { All players } \\
(n=11),{ }^{\ddagger} \\
\text { mean (SD) }\end{array}$ \\
\hline \multicolumn{2}{|l|}{ (kcal/kg BW) } & $45.4(9.0)$ \\
\hline${ }_{\text {est }} \mathrm{EA}(\mathrm{kcal} / \mathrm{kg}$ FFM) & $>30^{[11]}$ & $48.0(25.1)$ \\
\hline Protein (g/kg BW) & $\begin{array}{l}1.2-1.7^{[11]} \\
1.0-1.5^{[11]} \\
1.3-1.8^{[21]}\end{array}$ & $2.4(0.7)$ \\
\hline $\begin{array}{l}\text { Protein (without } \\
\text { supplements) (g/kg BW) }\end{array}$ & $\begin{array}{l}1.2-1.7^{[11]} \\
1.0-1.5^{[11]} \\
1.3-1.8^{[11]}\end{array}$ & $1.8(3.2)$ \\
\hline Carbohydrate (g/kg BW) & $6-10^{[11]}$ & $4.3(0.4)$ \\
\hline Fibre (g/day) & $25-30^{[18]}$ & $37.7(7.3)$ \\
\hline \multicolumn{3}{|l|}{ Fat } \\
\hline$\% \mathrm{TE}$ & $\begin{array}{l}20-35^{[11]} \\
30^{[11]} \\
15-20^{[11]}\end{array}$ & $33.8(4.3)$ \\
\hline g/kg BW & $1.0-1.5^{[11]}$ & $1.9(0.5)$ \\
\hline SFA (\%TE) & $10^{[18]}$ & $11.2(13.1)$ \\
\hline MUFA (\%TE) & $10^{[18]}$ & $11.2(1.5)$ \\
\hline PUFA (\%TE) & $10^{[18]}$ & $6.2(1.7)$ \\
\hline TFA (\%TE) & $<2^{[18]}$ & $0.8(0.4)$ \\
\hline \multicolumn{3}{|c|}{$\begin{array}{l}\mathrm{SD}=\text { standard deviation; } \mathrm{BW}=\text { body weight; } \text { cs }^{\mathrm{EA}}=\text { estimated energy availability; } \\
\text { FFM = fat-free mass; } \% \mathrm{TE}=\text { percentage of total energy; } \mathrm{SFA}=\text { saturated fatty acids; } \\
\text { MUFA = mono-unsaturated fatty acids; PUFA = polyunsaturated fatty acids; } \\
\text { TFA = trans fatty acids. }\end{array}$} \\
\hline \multicolumn{3}{|c|}{$\begin{array}{l}{ }^{*} \text { Reference range for macronutrients determined using the amount and level of training of the } \\
\text { rugby players (moderate levels of intense training } 2-3 \text { hours/day, } 5-6 \text { times/week; for moderate } \\
\text { levels of intense training the lower level of the range applies (as in this study population); for } \\
\text { high-volume intense training the upper level of the range applies). The dietary reference intakes } \\
\text { for healthy, physically active individuals were used as a reference range for micronutrient intake } \\
\text { - due to the high intake of the players the upper range was used to calculate percentage of total } \\
\text { intake. Players' intake was measured during the competitive season (January - February 2009). } \\
\text { 'Reference ranges provided are those published by the International Olympic Committee (IOC), } \\
\text { the American College of Sports Medicine (ACSM) and the International Society for Sports } \\
\text { Nutrition (ISSN), the details of which can be found in the review article cited (Potgieter, 2013 }{ }^{\left({ }^{11}\right)} \text { ). } \\
\text { ₹Of the } 11 \text { players who returned the 7-day food record, only eight indicated their position of } \\
\text { play (seven forwards, one back). }\end{array}$} \\
\hline
\end{tabular}

gain formulas, muscle builders, recovery enhancers, and protein and carbohydrate supplements.

\section{Nutritional match-day strategies}

Nutritional match-day strategies were determined for 18 players, of which 10 were forwards and 8 were backs. The macronutrient intake of the rugby players $>2$ hours before a rugby game was adequate for energy and carbohydrate intake; however, it was too high in protein and fat intake (Table 4). No significant differences were found between the pre-event meal of the forwards and of the backs. None of the subjects used supplements immediately before, during or immediately after a rugby match.
For the pre-event meal, all the players $(n=18)$ consumed chicken with skin (mean 140.0 (SD 62.0) g), orange juice (407.9 (207.7) $\mathrm{mL}$ ) and pasta (168.3 (104.0) g) and nine of the players (50\%) had eggs (2.7 (1.2) eggs) and brown bread (63.3 (18.0) g) in addition to the abovementioned.

No player consumed any food, supplement or sports drink during the rugby game, consuming only water $(954.6(762.1) \mathrm{mL})$. There was no significant difference between the mean fluid intake during the game between the forwards (1 $166.7(983.2) \mathrm{mL}$ ) and the backs (700.0 (308.2) $\mathrm{mL})(p=0.34)$.

The macronutrient intake after the game was higher than recommended for carbohydrate, protein and fat intake. The fluid $(p=0.02)$ and energy (including alcohol intake) $(p=0.04)$ intake was significantly higher after the game in the forwards compared with the backs. The players had a very high intake of alcohol after the rugby game, with higher alcohol consumption levels observed in the forwards than in the backs $(p=0.07$ ) (Table 6). Upon calculating the mean total energy intake without alcohol $(25.9(8.2) \mathrm{kcal} / \mathrm{kg})$, it was evident that the total energy intake was even lower than recommendations, although not statistically significant $(p=0.31)$.

For the post-event meal, all the players consumed one or more cans of soft drink (585.3 (420.9) mL), 14 (78\%) had pasta (107.1 (18.2) g), 13 (72\%) had beer (1 $326.2(869.9) \mathrm{mL}), 11(61 \%)$ had Steers Rave Burgers (1.5 (0.7) burgers) and 10 (56\%) had lasagne (187.5 (90.7) g). Only one player consumed a supplement after the rugby game, which provided $36 \mathrm{~g}$ carbohydrate per $400 \mathrm{~mL}$ fluid (9\% carbohydrate solution). The group consumed (5.4 (6.0) alcoholic beverages (6.9 (7.6) units) after the game, with forwards consuming 6.7 (6.7) beverages (8.5 (8.8) units) and backs 2.6 (3.5) beverages (3.4 (4.5) units).

\section{Discussion}

\section{Body composition}

Endurance, speed, agility, power, flexibility and sport-specific skills are important aspects of well-conditioned rugby players. ${ }^{[5]}$ The results from the present study showed distinct differences between the height, BW, body fat and FFM between the forwards and backs. This is substantiated by literature that has documented well-defined differences between the physical and morphological characteristics of forwards and backs, especially in terms of height and BW. ${ }^{[5,22-24]}$ The average BW of the forwards in our study $(\sim 107 \mathrm{~kg})$ was within the normal range when compared with SA data $(102-118 \mathrm{~kg})^{[20]}$ and that of New Zealand rugby players $(\sim 110 \mathrm{~kg})$. The average weight of the backs $(\sim 87 \mathrm{~kg})$ was just below the normal range compared with SA data ( $88-100 \mathrm{~kg}$ ) ${ }^{[20]}$ but was found to be $\sim 8 \mathrm{~kg}$ lighter when compared with that of NZ rugby players. ${ }^{[21]}$ National normative data presented by Boksmart were used as SA rugby players have shown to be able to compete at an international level. The mean (SD) BMI of the forwards was particularly high (32.5 (3.3) $\left.\mathrm{kg} / \mathrm{m}^{2}\right)$; according to the WHO this is classified as obese. However, the BMI should be interpreted with caution in physically active individuals, as it can incorrectly classify a very muscular person as being overweight. This is true for the backs in our study, as their BMI was $27.1(2.1) \mathrm{kg} / \mathrm{m}^{2}$, but their mean percentage body fat (15.8 (5.3)\%) was just above the national $(12-14 \%)^{[20]}$ and within international $(8-17 \%)^{[5]}$ recommendations for rugby players. The percentage body fat of the forwards ( $22 \%)$ was slightly above national recommend- 
Table 4. Macronutrient and fluid intake before a rugby game

\begin{tabular}{|c|c|c|c|c|c|}
\hline & Reference range ${ }^{\star}$ & $\begin{array}{l}\text { All players } \\
(n=18),{ }^{\dagger} \\
\text { mean (SD) }\end{array}$ & $\begin{array}{l}\text { Forwards } \\
(n=10), \\
\text { mean (SD) }\end{array}$ & $\begin{array}{l}\text { Backs } \\
(n=8), \\
\text { mean (SD) }\end{array}$ & $p$-value \\
\hline \multicolumn{6}{|l|}{$>2$ hours before the game } \\
\hline Energy (kcal/kg BW) & - & $27.2(8.3)$ & $25.8(8.6)$ & $29.2(8.1)$ & 0.44 \\
\hline \multirow[t]{3}{*}{ Carbohydrate (g/kg BW) } & $200-300(2-3 \text { hours prior })^{[11]}$ & $274.5(118.8)$ & $299.3(114.6)$ & $243.6(124.1)$ & 0.34 \\
\hline & $1-2(3-4 \text { hours prior })^{[11]}$ & $2.9(1.3)$ & $2.8(1.2)$ & $2.9(1.6)$ & 0.90 \\
\hline & $1-4(1-4 \text { hours prior })^{[11]}$ & & & & \\
\hline Protein (g/kg BW) & $0.15-0.25(3-4 \text { hours prior })^{[11]}$ & $1.2(0.6)$ & $1.2(0.4)$ & $1.1(0.7)$ & 0.90 \\
\hline Fat $(\mathrm{g} / \mathrm{kg} \mathrm{BW})$ & - & $0.9(0.4)$ & $1.0(0.4)$ & $0.9(0.5)$ & 0.64 \\
\hline Fluid (mL) & $\begin{array}{l}\text { Hydrate for normal urine } \\
\text { output }^{[11]}\end{array}$ & $1501.9(813.2)$ & $1674.0(796.7)$ & $1286.9(833.6)$ & 0.33 \\
\hline \multicolumn{6}{|l|}{1 hour before the game } \\
\hline Energy (kcal/kg BW) & - & $10.3(5.3)$ & $8.8(2.6)$ & $12.2(7.2)$ & 0.18 \\
\hline Carbohydrate (g/kg BW) & $1-4(1-4 \text { hours prior })^{[11]}$ & $1.1(0.6)$ & $1.0(0.5)$ & $1.3(0.7)$ & 0.31 \\
\hline $\operatorname{Protein}(\mathrm{g} / \mathrm{kg} \mathrm{BW})$ & - & $0.7(0.4)$ & $0.6(0.3)$ & $0.9(0.5)$ & 0.20 \\
\hline Fat (g/kg BW) & - & $0.3(0.2)$ & $0.3(0.2)$ & $0.3(0.3)$ & 0.53 \\
\hline Fluid (mL) & $\begin{array}{l}\text { Hydrate for normal urine } \\
\text { output }^{[11]}\end{array}$ & $408.4(375.8)$ & $485.1(437.1)$ & $312.5(280.0)$ & 0.26 \\
\hline \multicolumn{6}{|l|}{$\mathrm{SD}=$ standard deviation; $\mathrm{BW}=$ body weight. } \\
\hline
\end{tabular}

ations $(15-20 \%)^{[20]}$ and $\sim 5 \%$ above international recommendations $(8-17 \%) \cdot{ }^{[5]}$ Body fat insulates and protects organs and can play a vital role in providing a shield against physical impact experienced by forward players during scrumming; ${ }^{[5]}$ however, it does not contribute to the generation of muscle power and excessive amounts reduce a player's sprinting ability and influence heat tolerance. ${ }^{[22]}$ Backs require more speed as their position of play dictates more running during the game $\mathrm{e}^{[5]}$ with some tackling required. With increased proficiency in rugby, body fat percentage decreases and BW, specifically muscle mass, increases. ${ }^{[5]}$ The main function of muscle in sport is to contract and generate force, ${ }^{[22]}$ which improves exercise performance. ${ }^{[23]}$

The MVC team won the Varsity Cup in 2009 (the season in which body composition data was taken). This shows that although there are slight differences in body composition values when compared with national and international data, the team was performing effectively. Duthie et al. in $2003^{[5]}$ and $2006^{[22]}$ reported that during the 1999 Rugby World Cup, the most successful teams had higher total BW and that an increased percentage of body fat led to increased energy expenditure, with a subsequent reduction in the power-to-weight ratio and acceleration. The authors concluded that an increased BW is best carried by lean body mass, rather than body fat. Therefore, off-season recommendations for the MVC team could include inducing muscle hypertrophy, while reducing fat mass in forward players and increasing weight and muscle mass in backs. This can be achieved by implementing a suitable training programme (including resistance training) in order to provide the competitive advantage and decrease the risk of injury. In-season recommendations to the MVC team would include the maintenance of fitness, strength and power achieved preseason. How- ever, this can be difficult as there is an increased loss of muscle, strength and power during a rugby season because of the increased demand placed on a player's energy requirements due to training and competition.

\section{Habitual dietary intake and supplement use}

Comparing the group's habitual dietary intake to current recommendations, it was found that the group had an inadequate intake of TE, carbohydrate, PUFA, calcium:protein ratio and copper, and higher-than-recommended intakes for total protein, fibre, total fat, SFA, cholesterol and niacin. Although the players had a slightly lower than recommended TE intake, ${ }^{[11]}$ it compared favourably to energy intakes found in Japanese $(41 \mathrm{kcal} / \mathrm{kg} \mathrm{BW})^{[25]}$ and Australian rugby players $(\sim 44 \mathrm{kcal} / \mathrm{kg}$ and $\sim 49 \mathrm{kcal} / \mathrm{kg}$ BW for forwards and backs, respectively) ${ }^{[23]}$ It appeared from the cross-sectional body composition data that the MVC rugby players were ingesting sufficient TE. However, energy balance per se could not be determined as we only had body composition data of one time point during the MVC season. In addition, energy balance (energy in v. energy out) does not provide reliable information about energy requirements, and focuses on an output from rather than input to physiological systems. ${ }^{[1]}$ Therefore, determination of ${ }_{\text {est }} E A$ was of critical importance due to the fact that it is an indication of energy available after energy expended during exercise has been corrected for, thereby showing the impact of a low dietary intake on physiological functions. It has been shown that ${ }_{\text {est }} \mathrm{EA}<30 \mathrm{kcal} / \mathrm{kg}$ FFM impairs health and exercise performance by specifically suppressing type 1 immunity, which is important for fighting intracellular pathogens such as viruses that commonly cause upper respiratory tract infections in athletes. ${ }^{[11]}$ The high ${ }_{\text {est }}$ EA found 
Table 5. Macronutrient and fluid intake after the rugby game

\begin{tabular}{|c|c|c|c|c|c|}
\hline & Reference range $^{*}$ & $\begin{array}{l}\text { All players } \\
(n=18),{ }^{\dagger} \\
\text { mean (SD) }\end{array}$ & $\begin{array}{l}\text { Forwards } \\
(n=10), \\
\text { mean (SD) }\end{array}$ & $\begin{array}{l}\text { Backs } \\
(n=8), \\
\text { mean (SD) }\end{array}$ & $p$-value \\
\hline Energy (kcal/kg BW) & - & $29.6(9.8)$ & $31.21(10.0)$ & $27.5(9.7)$ & $0.04^{\ddagger}$ \\
\hline Energy without alcohol (kcal/kg BW) & - & $25.9(8.2)$ & $26.6(9.9)$ & $24.6(7.8)$ & 0.88 \\
\hline \multirow[t]{3}{*}{ Carbohydrate } & $1.0-1.5 \mathrm{~g} / \mathrm{kg} \mathrm{BW}[11]$ & $3.2(1.1)$ & $3.2(1.0)$ & $3.1(1.3)$ & 0.91 \\
\hline & $1.5 \mathrm{~g} / \mathrm{kg} \mathrm{BW}^{[11]}$ & & & & \\
\hline & $1-1.2 \mathrm{~g} / \mathrm{kg} \mathrm{BW} /$ hour $^{[11]}$ & & & & \\
\hline \multicolumn{6}{|l|}{ Protein } \\
\hline g & $20-25^{[11]}$ & $88.0(40.1)$ & $99.5(47.4)$ & $73.7(24.5)$ & 0.18 \\
\hline $\mathrm{g} / \mathrm{kg} \mathrm{BW}$ & $0.2-0.5^{[11]}$ & $0.9(0.4)$ & $0.9(0.4)$ & $0.9(0.3)$ & 0.68 \\
\hline Fat $(\mathrm{g} / \mathrm{kg} \mathrm{BW})$ & - & $1.0(0.5)$ & $1.0(0.6)$ & $1.0(0.3)$ & 0.71 \\
\hline \multicolumn{6}{|l|}{ Fluid } \\
\hline Immediately after (mL) & $\begin{array}{l}1000-1500 \text { (water and } \\
\text { sodium) })^{[11] \mathrm{s}}\end{array}$ & $433.9(732.3)$ & $578.0(922.6)$ & $253.8(375.8)$ & 0.37 \\
\hline After (mL) & & $\begin{array}{l}1744.2 \\
(1383.4)\end{array}$ & $\begin{array}{l}2400.5 \\
(1436.7)\end{array}$ & $923.8(780.6)$ & $0.02^{\ddagger}$ \\
\hline Alcohol (g) & - & $54.4(59.9)$ & $67.3(67.3)$ & $26.1(35.2)$ & 0.07 \\
\hline \multicolumn{6}{|c|}{$\mathrm{SD}=$ standard deviation; $\mathrm{BW}=$ body weight; $\mathrm{IOC}=$ International Olympic Committe. } \\
\hline $\begin{array}{l}\text { * Reference ranges provided are those published by the IOQ } \\
\text { the review article cited (Potgieter, } 2013^{(11)} \text { ). } \\
{ }^{+} 17 \text { players could not be reached via phone. } \\
\text { "S Statistically significant difference between forwards and } \\
\text { ' IOC recommends water and sodium to replace losses. } \\
\text { 'One drink of alcohol contains } 10 \mathrm{~g} \text { alcohol. }\end{array}$ & $\begin{array}{l}\text { the American College of Sports Medici } \\
\text { cks. }\end{array}$ & SM) and the Internatic & ociety for Sports Nutri & ISSN), the details of wh & an be found in \\
\hline
\end{tabular}

in the present study group indicated that the players are consuming sufficient energy to match their physical activity level; however, the backs could benefit from a properly designed training programme and dietary advice in order to increase their lean body mass by $\sim 2-8 \mathrm{~kg}$ in support of their position of play.

It appeared that the players were ingesting too much protein and fat, at the expense of carbohydrate, the most important macronutrient for exercise performance. In rugby specifically, owing to frequent bursts of short sprints ending in contact, and additional time spent scrumming and tackling, the emphasis is predominantly on carbohydrate utilisation. ${ }^{[12]}$ Rugby players can cover a distance of up to $10-15 \mathrm{~km}$ in a single game, which increases the risk of glycogen depletion and dehydration. ${ }^{[12]}$ In addition to providing fuel to sustain exercise during the game, carbohydrates also play a critical role in maintaining attention and decision-making abilities. ${ }^{[12]}$ If the rugby players were able to meet their carbohydrate requirements, the use of supplements to recover from exercise and to prevent fatigue would become redundant. Recommendations should be made that the participants increase their carbohydrate intake to within the required range. ${ }^{[11]}$ Ensuring appropriate timing of carbohydrate intake in relation to training sessions is also of vital importance to sustain and improve exercise performance. ${ }^{[1]}$ This is an important in-season recommendation, especially when the aim is to maintain fitness, strength and power. However, during the off-season, the MVC players are recommended to focus on achieving muscle hypertrophy (both forwards and backs) and therefore, recommendations (as provided by the IOC) should be made to include protein intake at $2.7 \mathrm{~g} / \mathrm{kg} \mathrm{BW}$ and carbohydrate intake at $3-4 \mathrm{~g} / \mathrm{kg} \mathrm{BW}^{[11]}$ during hypoenergetic periods. For this study period, the rugby players were closer to meeting these requirements than those according to their activity level.

Total habitual protein intake (with supplements, $\sim 2.4 \mathrm{~g} / \mathrm{kg} \mathrm{BW}$ ) exceeded the recommended range. ${ }^{[11]}$ Compared with sedentary individuals $(0.8 \mathrm{~g} / \mathrm{kg} \mathrm{BW})$, athletes have increased daily protein requirements. ${ }^{[1]}$ However, increasing protein intake beyond elevated requirements for athletes $(1.0-1.8 \mathrm{~g} / \mathrm{kg} \mathrm{BW}$, increased to $2.7 \mathrm{~g} / \mathrm{kg} \mathrm{BW}$ when a change in body composition is desired out of season) is not recommended. Timing of protein intake is an important factor, as is taking into consideration the total energy intake and carbohydrate intake in order to optimise adaptations to training. The majority of the participants took protein supplements and indicated the reason being to recover from exercise. The protein intake calculated without the supplements amounted to $\sim 1.8 \mathrm{~g} / \mathrm{kg} \mathrm{BW}$, which was much closer to in-season protein recommendations; therefore, additional supplement use should be limited. In a study on 247 Canadian university athletes, a prevalence of $98.6 \%$ supplement use was found; among males these included carbohydrate gels, protein powders and creatine. ${ }^{[26]}$ In Singapore, a study completed by Tian et al. ${ }^{[27]}$ found a prevalence of $76.8 \%$ supplement use in 82 university athletes, which averaged to about two supplements per day. While an adequate intake of protein is necessary to recover from exercise and can be beneficial in terms of muscle adaptation, the players had a high habitual protein intake, attenuating the need for additional supplementation. The low calcium:protein ratio indicates that the players were consuming a high amount of protein in relation to their calcium intake. Although the calcium intake per se was adequate when 
compared with the DRI, in relation to protein intake it was not sufficient. Although most of the supplements consumed contained between 200 and $250 \mathrm{mg}$ calcium per $100 \mathrm{~g}$ product, labelling of the supplements was inconsistent and consumption could not be quantified. The ratio of calcium:protein (without supplements) was $~ 7: 1$, compared with the Prudent dietary recommendation of 20:1. Recommendations could be made to align protein and calcium intakes as this would allow for sufficient calcium absorption; at this stage in their development (age), this would be of vital importance in terms of bone mineralisation, as up to $90 \%$ of peak bone mass is acquired by 20 - 30 years of age. As protein can also have a beneficial effect on bone health, athletes could focus on including calcium-rich sources of protein, such as dairy and dairy products. ${ }^{[28]}$ Weight-bearing exercise also plays a protective role in terms of bone health, which in the current study population formed part of their conditioning programme. A combination of weight-bearing exercise, appropriate increase in muscle mass and recommended alignment of protein intake would ensure optimal bone health for these (and other) rugby players.

The rugby players' total habitual fat intake was at the upper end of the range recommended by the American College of Sports Medicine $(\mathrm{ACSM})^{[11]}$ and exceeded the recommended range established by the IOC. ${ }^{[1]}$ PUFA intake was inadequate, whereas SFA and dietary cholesterol intake exceeded recommendations consistent with good health. This can lead to an increased risk of heart disease, among other diseases of lifestyle, and may have a negative effect on the players' rugby performance. ${ }^{[4]}$ The forwards are recommended to modify their eating habits in this regard to decrease body fat percentage.

The micronutrient intake of the rugby players in the present study was found to be adequate, except for a low copper intake and a high niacin intake. The elevated niacin intake could have been due to a high habitual intake of chicken and tuna. There are no known symptoms of toxicity of increased dietary niacin intake; however, with supplementation, levels exceeding $3 \mathrm{mg} /$ day can cause flushing, headaches, nausea, vomiting and liver toxicity. ${ }^{[18]}$ There are currently no clear guidelines supporting additional micronutrient supplementation in physically active individuals. ${ }^{[11]}$ A healthy, balanced diet, which includes all the different food groups, and adequate exposure to sunlight should provide sufficient micronutrients.

Optimising the habitual dietary intake of the study group is a challenge. The MVC rugby players are university students as well as semi-professional rugby players, and striking a balance between the two can be difficult. Although not specifically recorded in this study, many of the players stay in residences on campus, where meals are provided and they have little control over their dietary intake. Student life can also include binge-drinking episodes, which can impact on training and rugby performance.

Nutritional match-day strategies: before, during and after a match Dietary intake during competition forms part of a specific shortterm nutritional strategy aimed at maximising performance at that particular time. ${ }^{[1]}$ The macronutrient intake of the rugby players $>2$ hours before the rugby game was adequate for energy and carbohydrate intake, but was high in protein and fat. This was due to popular food choices including chicken with skin, eggs, bacon, muffins and cheese. The players had not received any formal nutritional education and they did not receive a standardised pre-event meal. The only guideline available in terms of pre-event protein intake is from the IOC, which states that although preliminary evidence appears to support increased muscle protein synthesis in response to resistance training when protein is given before exercise, follow-up studies have failed to confirm this finding. Athletes can employ this strategy during training when resistance exercise forms part of their conditioning programme; however, before games it is not necessary. A high fat intake is not recommended before an event, as this slows down gastric emptying and may cause gastrointestinal upset. ${ }^{[1]}$

The subjects ingested $\sim 1 \mathrm{~L}$ of water during the rugby game. The combined recommendation from the IOC, ACSM and International Society for Sports Nutrition (ISSN) is to calculate individual fluid needs in order to prevent hyper- and hypohydration. ${ }^{[1]}$ The ISSN recommends drinking $500-2000 \mathrm{~mL}$ fluid during every hour of exercise (150 - $200 \mathrm{~mL}$ every 15 - 20 minutes). ${ }^{[11]}$ Although this may seem like an impractical guideline because of restricted opportunity to take in fluid, the players in the present study were comfortably reaching this recommendation with their intake of water. Several studies have shown that the start of fatigue during exercise overlaps with the depletion of glycogen in the exercising muscles, and that the fluid recommendation is more a vehicle to provide carbohydrate to improve exercise performance rather than to prevent dehydration (as dehydration in some cases will not impair performance) ${ }^{[11]}$ Additional studies have shown that ingestion of carbohydrates during exercise can reduce immunosuppressive effects of exercise and promote muscle glycogen recovery. ${ }^{[11]}$ In addition, carbohydrate intake during exercise can improve cognitive function and tactical decision-making, which is especially important during the second half when blood glucose levels decrease. None of the players in the present study consumed any food, supplements or sports drinks during the rugby game. It is recommended that they consume $30-60$ g carbohydrate per hour of exercise. ${ }^{[11]}$ In addition to the 10 -minute half-time break, the Varsity Cup provides a 2-minute break in each half (any 2 minutes between the 18th and 22nd minutes in the first half and between the 58th and 62nd minutes in the second half). Recommendations should be made to use halftime and the strategic-break time to consume at least 250 - $300 \mathrm{~mL}$ of a carbohydrate-electrolyte solution.

Postexercise consumption of carbohydrates promotes recovery from exercise and replenishes depleted glycogen stores. ${ }^{[1]}$ The group of rugby players in the study had sufficient and even higher-thanrecommended intake of carbohydrate and protein. There is consensus from the ACSM, ISSN and IOC on the beneficial effect of the ingestion of $\sim 20 \mathrm{~g}(0.2-0.5 \mathrm{~g} / \mathrm{kg})$ protein with carbohydrates within 30 minutes post exercise. This recovery strategy can be achieved through dietary sources and additional supplementation is not warranted. ${ }^{[11]}$ Although the players had a high intake of alcohol, their postgame energy and carbohydrate intake when calculated without alcohol was still sufficient when compared with recommendations. However, alcohol does interfere with the body's ability to replenish muscle glycogen and impairs recovery, as discussed below. ${ }^{[29]}$ The fluid intake of the forwards (excluding alcohol) was significantly higher compared with the backs, but both groups reached IOC and ACSM requirements to replace water and sodium losses. ${ }^{[11]}$

The players had a very high intake of alcohol after the rugby game, with almost significantly higher levels found in the forwards 
compared with the backs. The players' alcohol intake after the match was found to contribute a large amount to their energy and carbohydrate intake, as the drink of choice was beer. Consuming alcohol on Monday nights after a Varsity Cup game has become culture among university students in SA and the players in the present study were no exception. Drinking alcohol after exercise has been shown to increase urinary losses during postrecovery exercise, leading to further dehydration and impeded muscle repair processes. Alcohol has vasodilatory effects on the cutaneous blood vessels and may increase swelling around injured areas, in contrast to the swellingdelaying vasoconstrictive practices such as treating with ice, rest and elevation. ${ }^{[29]}$ To the authors' knowledge, there are no published studies in SA reporting the prevalence of alcohol use after a rugby game. However, studies that have been conducted in Germany have found a prevalence of $24 \%$ for binge drinking (in 1 month) in 1138 German Young Olympic Athlete's Lifestyle (GOAL) and Health Management Study athletes. The GOAL study also reported a positive relationship between binge drinking and age, education, technical sports, athletes in the lower squads and athletes staying in residences. ${ }^{[30]}$ Similarly, studies on French athletes showed a prevalence of $20.4 \%$ of bingedrinking episodes in 677 sport science students. ${ }^{[31]}$ In a study on the impact of alcohol consumption on recovery, it was found that acute binge drinking ( $1 \mathrm{~g}$ alcohol/kg BW) after a rugby game adversely affected sleep patterns, lead to increased muscle weakness and decreased lower body vertical power output for days after the game, and that club rugby players were subjected to alcohol-related harm following binge-drinking episodes. ${ }^{[32]}$ It is recommended that the players receive nutrition education, specifically with regard to the effect of alcohol on recovery after exercise. Players could perhaps rather include a low alcohol beer with added sodium, which could be socially acceptable but not increase fluid losses after exercise.

\section{Study limitations}

A limitation of the present study is that the body composition data obtained were routine data obtained by a biokineticist; due to time constraints and interobserver variability, the fieldworkers could not obtain the outstanding body composition sets. Food records are known to place a large burden on subjects and with the present study taking place over 7 days, subject compliance $(31 \% ; n=11)$ and response rate were influenced. Other known limitations of food records include over- and/or underreporting to make a good impression, and simplifying diet because of recording and literacy issues.

\section{Conclusions}

Conclusions of this study with regard to habitual dietary intake should be drawn with caution due to the small sample size. Future studies should aim to include a larger cohort and to compare the habitual/ training dietary intake of the forwards and backs.

Results from this study indicate that, as expected, there was a definite distinction in the physical characteristics of the forwards and backs of the MVC rugby team. Habitual nutritional intake was inadequate for total energy (although adequate for ${ }_{\text {est }}$ EA), carbohydrate, PUFA, calcium:protein ratio and copper, with high habitual supplement use. The group had higher-than-recommended intakes for total protein, fibre, total fat, SFA, cholesterol and niacin. Nutritional match-day strategies were suboptimal. Dietary intake and body composition are important complementary factors of the fitness of any rugby player, therefore instilling values with regard to correct timing of nutrient intake and informed use of supplements is of great importance. Players of the MVC rugby team could potentially benefit significantly from specialist input, to optimise dietary strategies and body composition to enhance performance. A registered dietitian specialising in sport nutrition could provide individual recommendations (including supplement advice), as well as recommendations for team protocols on prematch menus and food/drink during and after matches. In addition, recommendations on appropriate alcohol consumption should be made, especially in light of optimal recovery strategies and keeping in mind that although this group is considered semi-professional, they are also university students.

Acknowledgements. The authors would like to thank the coaching staff at the Stellenbosch Rugby Football Club, as well as Dr P Vivier and his team from Campus Health Services, Stellenbosch University.

\section{References}

The reference list has been truncated because of the limited number of references permitted by the journal. Additional references are available on request from the corresponding author.

1. South African Rugby Union (SARU) Annual Report 2012. http://www.sarugby.net/ content.aspx?contentid=19255 (accessed 15 August 2013).

2. First National Bank, Steinhoff International. FNB Varsity Cup presented by Steinhoff International. http://varsitycup.co.za/footer-links-5/about-us (accessed 15 August 2013).

3. Stellenbosch Rugby Football Club. http://www.matiesrugby.co.za/about-us (accessed 15 August 2013).

4. Lako J, Sotheeswaran S, Christi K. Food habits and nutritional status of Fiji rugby players. World Ac Sci Eng Tech 2010;4:752-757. http://waset.org/publications/11286 (accessed 21 November 2013).

5. Duthie G, Pyne D, Hooper S. Applied physiology and game analysis of rugby union. Sports Med 2003;33(13):973-991. [http://dx.doi.org/10.2165/00007256-200333130-00003]

6. Duthie GM, Pyne DB, Hopkins WG, et al. Anthropometry profiles of elite rugby players: Quantifying changes in lean mass. Br J Sports Med 2006;40(3):202-207. [http://dx.doi. org/10.1136/bjsm.2005.019695]

7. Maud PJ. Physiological and anthropometric parameters that describe a rugby union team. Br J Sports Med 1983;17(1):16-23. [http://dx.doi.org/10.1136/bjsm.17.1.16]

8. Durandt J, Du Toit S, Borreson J, et al. Fitness and body composition profiling of elite junior South African rugby union players. South African Journal of Sports Medicine 2006;18(2):38-45. http://www.ajol.info/index.php/sasma/article/viewFile/31896/5912 (accessed 21 November 2013).

9. Quarrie KL, Handcock P, Toomey MJ, Waller AE. The New Zealand rugby injury and performance project. IV. Anthropometric and physical performance comparisons between positional categories of senior A rugby players. Br J Sports Med 1996;30(1):5356. [http://dx.doi.org/10.1136/bjsm.30.1.53]

10. Quarrie KL, Handcock P, Waller AE, et al. The New Zealand rugby injury and performance project. III. Anthropometric and physical performance characteristics of players. Br J Sports Med 1995;29(4):263-270. [http://dx.doi.org/10.1136/bjsm.29.4.263]

11. Potgieter S. Sport Nutrition: A review of the latest American College of Sports Medicine (ACSM), International Olympic Committee (IOC) and International Society for Sports Nutrition (ISSN) guidelines for exercise and sport nutrition. South African Journal of Clinical Nutrition 2013;26(1):6-16. www.ajol.info/index. $\mathrm{php} / \mathrm{sajcn} /$ article/download/88379/77991 (accessed on 21 November 2013). (Primary references are available on request from the corresponding author.)

12. Holway FE, Spriet LL. Sports-specific nutrition: Practical strategies for team sports. J Sports Sci 2011;29(S1):S115-S125. [http://dx.doi.org/10.1080/02640414.2011.605459]

13. International Rugby Board (IRB). Strength and Conditioning. http://www.irbsandc. com/?module $=5 \&$ section $=24 \&$ subsection $=62$ (accessed 21 November 2013 ).

14. World Health Organization. Body Mass Index Classification. http://www.apps.who.int/ bmi/index.jsp?introPage=intro_3.html (accessed 24 January 2011).

15. Burke LM, Deakin V. Clinical Sports Nutrition, 4th ed. Australia: McGraw-Hill, 2009.

16. Jackson AS, Pollock M. Practical assessment of body composition. Phys Sport Med 1985;13:76-90.

17. FoodFinder ${ }^{\circ}$ Nutritional Intervention Research Unit (NIRU) and Biomedical Informatics Research Division (BIRD) of the South African Medical Research Council (MRC) in collaboration with WAMTechnology CC. http://foodfinder.mrc.ac.za/ (accessed 21 November 2013). 
18. Nutrition Information Centre of the University of Stellenbosch (NICUS). Dietary Reference Intakes. South Africa: National Academy Press, 2003. http://sun025.sun.ac.za/ portal/page/portal/Health_Sciences/English/Centres\%20and\%20Institutions/Nicus (accessed 21 November 2013).

19. Davies KM, Heaney RP, Recker RR, et al. Calcium intake and body weight. J Clin Endocrinol Metab 2000;85(12):4635-4638. [http://dx.doi.org/10.1210/jcem.85.12.7063]

20. BokSmart. Normative Data (Average + SD) form, Senior. http://www.sarugby.co.za/ boksmart/pdf/BokSmart\%20-\%20normative\%20data\%20(display\%20only\%20 Average\%20SD)\%20SENIOR.pdf (accessed 21 November 2013).

21. Quarrie KL, Hopkins. Changes in player characteristics and match activities in Bledisloe Cup rugby union from 1972 to 2004. J Sports Sci 2007;25(8):895-903. [http://dx.doi. org/10.1080/02640410600944659]

22. Lambert MI. Aspects of physical conditioning for rugby. Boksmart. http://boksmart. sarugby.co.za (accessed 16 August 2013).

23. Lundy B, O'Connor H, Pelly F, Caterson L. Anthropometric characteristics and competition dietary intakes of professional rugby league players. Int J Sport Nutr Exerc Metab 2006;16(2):199-213.

24. Sedeaud A, Marc A, Schipman J, et al. How they won Rugby World Cup through height, mass and collective experience. Br J Sports Med 2012;46(8):580-584. [http://dx.doi. org/10.1136/bjsports-2011-090506]
25. Imamura $\mathrm{H}$, Iide $\mathrm{K}$, Yoshimura $\mathrm{Y}$, et al. Nutrient intake, serum lipids and iron status of colligiate rugby players. J Int Soc Sports Nutr 2013;10:9. [http://dx.doi.org/10.1186/1550-2783-10-9]

26. Kristiansen M, Levy-Milne R, Barr S, et al. Dietary supplement use by varsity athletes at a Canadian University. Int J Sport Nutr Exerc 2005;15(2):195-210.

27. Tian HH, Ong WS, Tan CL. Nutritional supplement use among univarsity athletes in Singapore. Singapore Med J 2009;50(2):165-72

28. Phillips SM, Moore DR, Tang JE. A critical examination of dietary protein requirements, benefits and excesses in athletes. Int J Sport Nutr Exerc Metab 2007;17:S58-S76.

29. Burke LM, Collier GR, Broad EM, et al. Effect of alcohol intake on muscle glycogen storage after prolonged exercise. J Appl Physiol 2003;95(3):983-990. [http://dx.doi.org/10.1152/ japplphysiol.00115.2003]

30. Thiel A, Diehl K, Giel KE, et al. The German young olympic athletes' lifestyle and health management study (GOAL Study): Design of a mixed-method study. BMC Public Health 2011;11:410. [http://dx.doi.org/10.1186/1471-2458-11-410]

31. Lorente FO, Souville M, Griffet J, et al. Participation in sports and alcohol consumption among French adolescents. Addict Behav 2004;29(5):941-946. [http://dx.doi.org/10.1016/j. addbeh.2004.02.039]

32. Prentice C, Stannard SR, Barnes MJ. The effects of binge drinking behaviour on recovery and performance after a rugby match. J Sci Med Sport 2014;17(2):244-248. [http://dx.doi. org/10.1016/j.jsams.2013.04.011] 